\title{
LONG-TERM EFFECTS OF SHORT-TERM PERTURBATION IN A SUBALPINE GRASSLAND
}

\author{
Thomas Siegelberger, ${ }^{1,5}$ Otto Hegg, ${ }^{2}$ Diethart Matthies, ${ }^{3}$ Katarina Hedlund, ${ }^{4}$ and Urs Schaffner ${ }^{1}$ \\ ${ }^{1}$ CABI Bioscience Switzerland, Rue des Grillons 1, CH-2800 Delémont, Switzerland \\ ${ }^{2}$ University of Berne, Geobotanical Institute, Altenbergrain 21, CH-3013 Bern, Switzerland \\ ${ }^{3}$ University of Marburg, Department of Biology, Karl-von-Frisch-Straße 8, D-35032 Marburg, Germany \\ ${ }^{4}$ University of Lund, Department of Ecology, Sölvegatan 37, S-22362 Lund, Sweden
}

\begin{abstract}
Theoretical advances and short-term experimental studies have furthered our understanding of how ecosystems respond to perturbation. However, there are few wellreplicated experimental studies that allow an assessment of long-term responses. Results from a controlled, large-scale field experiment in a subalpine grassland near Interlaken, Switzerland, show that 2-4 years of liming $\left(\mathrm{Ca}: 40 \mathrm{~g} \cdot \mathrm{m}^{-2} \cdot \mathrm{yr}^{-1}\right)$ still significantly affected the composition of the vegetation and the soil microbial community nearly 70 years after the treatments were imposed, whereas NPK fertilization $\left(8 \mathrm{~g} \cdot \mathrm{m}^{-2} \cdot \mathrm{yr}^{-1}\right)$ only marginally affected vegetation composition. The exchangeable content of $\mathrm{Ca}$ ions and soil $\mathrm{pH}$ were higher in limed plots but were unaffected in fertilized plots. Plant species and PLFAs (phospholipid fatty acids) indicating low $\mathrm{pH}$ values were found in higher abundance in the unlimed plots, suggesting that the long-lasting effects of liming on the above- and belowground communities were mediated through changes in soil $\mathrm{pH}$. The results of this long-term study indicate that the resilience of mountain ecosystems may be particularly low in response to perturbations that substantially alter soil $\mathrm{pH}$ or other key determinants of belowground processes.
\end{abstract}

Key words: lime; long-term effects; mountain grasslands; phospholipid fatty acids (PLFAs); soil nutrients; soil pH.

\section{INTRODUCTION}

Long-term experiments in seminatural and natural terrestrial ecosystems have revealed that continuous human influences, such as the input of nutrients or acid rain, can have dramatic effects on the composition of communities and on ecosystem functioning (Tilman and Lehman 2001). For example, the Park Grass experiments at Rothamsted, UK, which started in 1856, have revealed that continuous fertilizer or liming amendments to the soil significantly changed soil $\mathrm{pH}$, the composition of the vegetation and the soil microbial community, plant species richness, litter decomposition, and soil development (Johnston et al. 1986, Tilman et al. 1994). However, little is known about whether ecosystems are resilient in the long term against short-term perturbations (Scheffer et al. 2001). Two types of resilience have been proposed. After disturbance components of resilient ecosystems may either return to their original state (resilience sensu May 1973), or may undergo a transition toward an alternative stability domain (ecological resilience sensu Holling 1973; see also Gunderson 2000 and Scheffer et al. 2001).

Theoretical and experimental work suggest that resilience is affected by a number of ecosystem characteristics, including nutrient cycling (DeAngelis et al. 1989,

Manuscript received 27 March 2006; accepted 28 March 2006. Corresponding Editor: D. A. Wardle.

${ }^{5}$ E-mail: t.spiegelberger@cabi.org
Moore et al. 1993), plant functional types (Leps et al. 1982, MacGillivray and Grime 1995), and ecological diversity (Tilman and Downing 1994). The "resilienceproductivity hypothesis" posits that the time required by an ecosystem to regain equilibrium after a disturbance is similar to the turnover time of nutrients in the system (DeAngelis et al. 1989, Moore et al. 1993), suggesting that resilience may be particularly low in ecosystems with harsh environmental conditions, like alpine and arctic ecosystems. Plant species growing in alpine and arctic ecosystems are characterized by a set of traits that promote the tolerance of environmental stresses (Körner 1999). The same traits are associated with low growth rates and are therefore predicted to be associated with low rates of resilience (Leps et al. 1982, MacGillivray and Grime 1995). Moreover, resilience is likely to vary not only among ecosystems, but also among components and processes within the same ecosystem (Lavorel et al. 1999). For example, recovery of vegetation cover may be relatively fast, while recovery of vegetational composition might be considerably slower.

Here, we report results from a controlled, large-scale field experiment on the long-term effects of liming and fertilization on the composition of the plant and microbial community of a subalpine grassland. The treatments were carried out from 1932 to 1935 and led to a significant shift in plant species composition within a few years. We revisited the experimental site nearly 70 years after the treatments were imposed to test the 
hypothesis that liming and NPK fertilization still affected vegetation composition. We also aimed to test whether the short-term addition of lime and NPK fertilizer had long-term effects on soil chemical properties and on the composition of the soil microbial community.

\section{Methods}

The experiment at the Schynige Platte near Interlaken (Bernese Oberland, Switzerland) was set up in 1930 by Werner Lüdi at $1925 \mathrm{~m}$ above sea level in a subalpine acid grassland (acid cambisol, $\mathrm{pH}$ at the beginning of the experiment 4.5-5.0 [Lüdi 1948]) on a south-southeastfacing slope with an inclination of $20^{\circ}$. Mean annual precipitation is $\sim 1800 \mathrm{~mm}$, and mean annual temperature is $\sim 1^{\circ} \mathrm{C}$. Before 1930, the site had been used as a pasture for many centuries. Once the experimental plots had been set up and the treatments initiated, the whole site was fenced, and was mowed once a year in late summer. From 1958 to 1980 the site was grazed by cattle. Since 1980, the site has been fenced again and maintained by one of the authors $(\mathrm{O}$. Hegg) by mowing it once a year. The vegetation of the site consisted mainly of grasses, in particular Nardus stricta L. and Festuca rubra L. with an average cover of $\sim 30 \%$ and $5 \%$, respectively. Subordinate species with an average cover of between 3\% and 5\% were Arnica montana L., Crepis conyzifolia (Gouan) Kerner, Gentiana purpurea L., and Vaccinium myrtillus L. Bryophytes and lichens were rare in the experimental plots and were not recorded.

We present results from a subset of 80 plots out of the 340 plots set up by W. Lüdi. The plots, each $2.56 \mathrm{~m}^{2}$ (1.6 $\times 1.6 \mathrm{~m}$ ), separated by $0.4 \mathrm{~m}$ wide access paths, were arranged in four blocks. Each block consisted of 20 plots, which were subjected in a factorial design to the two treatments: liming (yes/no) and NPK fertilizer (yes/ no). Both treatments were applied in all blocks once a year in early summer 1932 and 1933. In two of the four blocks, the treatments were repeated in 1934 and 1935. $\mathrm{N}$ was applied as ammonium sulphate, $\mathrm{P}$ as superphosphate, and $\mathrm{K}$ as potassium (Hegg et al. 1992). The fertilized plots also received a small amount of $\mathrm{Ca}$ as part of the $\mathrm{P}$ fertilizer. In total, plots that were limed over a period of two years received $80 \mathrm{~g} / \mathrm{m}^{2} \mathrm{Ca}$, and plots that were fertilized received $1.4 \mathrm{~g} / \mathrm{m}^{2} \mathrm{~N}, 4.9 \mathrm{~g} / \mathrm{m}^{2} \mathrm{P}$, $9.7 \mathrm{~g} / \mathrm{m}^{2} \mathrm{~K}$, and $19 \mathrm{~g} / \mathrm{m}^{2} \mathrm{Ca}$. Plots that were treated over a period of four years received twice the amount of nutrients compared to those treated over a period of two years. The 20 plots of each block were arranged in two parallel rows of 10 plots along the main altitudinal gradient. The four treatment combinations were allocated to the plots in a regular design.

In summer 2002 complete plant species lists were established for the central $1-\mathrm{m}^{2}$ square of each plot. Then, the cover of each vascular plant species was estimated to the nearest 1\% (Mueller-Dombois and Ellenberg 1974). Cover for species with $<1 \%$ cover was assessed with greater precision by placing a $10 \times 10 \mathrm{~cm}$ square frame ( $1 \%$ of the $1-\mathrm{m}^{2}$ square) over each plant of a species and summing the estimated cover for all plants of that species. Cover was evaluated for each species independently so that the sum of cover values could exceed $100 \%$ and reflect canopy layering. Soil samples were collected on 9 August 2003. In each plot, four soil cores (diameter $18 \mathrm{~mm}$, depth $10 \mathrm{~cm}$ ) were taken with a metal sampler next to the four corners of the central 1$\mathrm{m}^{2}$ subplot, pooled, and transferred to a deep-freezer $\left(-18^{\circ} \mathrm{C}\right)$ within a few hours after sampling. The soil samples were then homogenized and sieved (mesh size 2 $\mathrm{mm})$. Organic matter content was determined by reweighing $3 \mathrm{~g}$ of dry soil after burning at $400^{\circ} \mathrm{C}$ for 8 $\mathrm{h}$. The exchangeable content of $\mathrm{Ca}$ and $\mathrm{K}$ was determined in an inductively coupled plasma spectrophotometer (Optima 3000 DV, PerkinElmer, Wellesley, Massachusetts, USA) after dissolving $5 \mathrm{~g}$ of dry soil for $2 \mathrm{~h}$ in $0.1 \mathrm{~mol} / \mathrm{L} \mathrm{BaCl}_{2}$. To make the soil $\mathrm{pH}$ measurements comparable with those from previous studies (Lüdi 1959, Hegg et al. 1992), pH was measured after shaking $5 \mathrm{~g}$ of soil in $5 \mathrm{~mL}$ of distilled water for $15 \mathrm{~min}$. Lipid extractions were made from $3 \mathrm{~g}$ soil as described by Hedlund (2002). The sum of the phospholipid fatty acids (PLFA) i15:0, a15:0, 15:0, i16:0, 16:1 a17:0, cy17:0, 18:1 1 , and cy19:0 was used as an index of bacterial biomass (Frostegård and Bååth 1996). The amount of PLFA 18:206 was used as an index of saprophytic fungal biomass and the neutral lipid fatty acid (NLFA) 16:105 as a marker for arbuscular mycorrhizal fungi (Olsson 1999, Hedlund 2002). All PLFA and NLFA concentrations were expressed as nanomoles per gram of dry soil.

To assess the productivity of the 80 plots, a bioassay was carried out using Festuca rubra L. as a phytometer. A bioassay was preferred to an analysis of soil nitrogen, because nutrient availability for plants is often only weakly related to element concentrations in the soil (Schimel and Bennett 2004). F. rubra is a species with a wide ecological amplitude with respect to $\mathrm{pH}$ (Ellenberg et al. 1991). Sieved and homogenized soil samples from each of the 80 plots were placed in plastic tubes (diameter $2 \mathrm{~cm}$, height $8 \mathrm{~cm}$ ), which were tightly closed by a $55-\mu \mathrm{m}$ gauze screen at the bottom. The tubes were individually placed in cups and randomly arranged on a greenhouse bench. Two seedlings of $F$. rubra were planted in each tube. Seedlings that died within five days after transplanting were replaced. Plants received regularly the same amount of water. After 10 weeks the seedlings were harvested, dried for 48 hours at $80^{\circ} \mathrm{C}$, and weighed.

We subdivided all experimental blocks into an upper and a lower half to take into account the altitudinal gradient at the site, which resulted in a total of eight blocks containing 2-3 replicates of each of the four treatment combinations. All analyses were based on 80 soil samples and 79 vegetation records (one census was lost). The statistical power to detect the effects of factors that varied at the block level (duration of fertilizer application, i.e., two or four years, and position of plot 
TABLE 1. Results of redundancy analyses of the effects of NPK-fertilization and liming in the 1930s on the composition of the plant community of a subalpine pasture in 2002, and on the microbial community in 2003.

\begin{tabular}{|c|c|c|c|c|c|c|c|c|}
\hline \multirow[b]{2}{*}{ Source } & \multicolumn{4}{|c|}{ Plant community (2002) } & \multicolumn{4}{|c|}{ Soil microbial community (2003) } \\
\hline & df & Total ss & $F$ & $P$ & df & Total ss & $F$ & $P$ \\
\hline Block & 7 & 0.181 & & & 7 & 0.174 & & \\
\hline NPK & 1 & 0.015 & 1.39 & 0.083 & 1 & 0.013 & 1.137 & 0.331 \\
\hline Liming & 1 & 0.042 & 3.81 & $<\mathbf{0 . 0 0 1}$ & 1 & 0.029 & 2.604 & 0.009 \\
\hline NPK $\times$ liming & 1 & 0.008 & 0.70 & 0.898 & 1 & 0.005 & 0.443 & 0.920 \\
\hline Error & 68 & 0.754 & & & 69 & 0.779 & & \\
\hline Total & 78 & 1.000 & & & 79 & 1.000 & & \\
\hline
\end{tabular}

Notes: $P$ values are derived from randomization tests (ter Braak and Smilauer 1999). Significant test results are in boldface type.

along the slope) was very low due to low replication, and no effects were found. All analyses were therefore carried out using the factors block, fertilization, and liming. Univariate data were analyzed by analyses of variance using the $\mathrm{R}-1.8 .1$ statistical language ( $\mathrm{R}$ Development Core Team 2004). To fulfill the assumptions of normally distributed residuals and homogeneity of variances data were transformed in some cases prior to analysis.

For the multivariate analyses of community composition, the data on individual plant cover were logtransformed, and the individual PLFA amounts were divided by the sum of all PLFAs and then also logtransformed prior to analysis. Initial detrended correspondence analyses showed that beta diversity (gradient length) of the communities was relatively low (1.83), and following the recommendations of Leps and Smilauer (2003) the data were therefore analyzed by redundancy analysis, a constrained form of principal component analysis (van den Wollenberg 1977). The method used by us to record the vegetation (Mueller-Dombois and Ellenberg 1974) includes a visual and therefore potentially subjective estimation of the cover of the individual plant species, but has the advantage of providing a complete species list for each plot. To test for a potential bias due to the visual estimation of species cover, we also carried out a canonical correspondence analysis of the vegetation composition using species presence-absence data. All multivariate analyses were carried out using CANOCO 4.02 (ter Braak and Smilauer 1999). The significance of the treatments was tested using the randomization test available in CANOCO.

To identify plant species and phospholipid fatty acids indicating the treatments imposed, indicator species analyses (Dufrene and Legendre 1997) followed by randomization tests were carried out with the logtransformed data using PC-ORD (McCune and Mefford 1999). Indicator species analysis combines information on the relative abundance of a species and its relative frequency of occurrence in groups of sites (Dufrene and Legendre 1997).

\section{RESUlts}

Nearly 70 years after the last liming treatment, both the soil $\mathrm{pH}\left(5.14 \pm 0.04\right.$ vs. $4.97 \pm 0.04, F_{1,69}=13.0, P$
$<0.001)$ and the exchangeable content of $\mathrm{Ca}$ ions (181 \pm 9.0 vs. $\left.148 \pm 9.6 \mathrm{mg} / \mathrm{L}, F_{1,69}=9.9, P=0.002\right)$ were significantly higher in limed than in unlimed plots (data are given as means and standard errors). In contrast, fertilization had no effect on either the $\mathrm{pH}$ or the exchangeable content of $\mathrm{Ca}$ ions (both $P>0.5$ ). Furthermore, $\mathrm{K}$ ions and organic matter content were not significantly affected by any of the treatments (all $P$ $>0.1$, and treatments did not influence the aboveground biomass of the phytometer $F$. rubra in the bioassay (all $P>0.15$ ). Plant species richness per plot increased with soil $\mathrm{pH}$ (linear regression, $r=0.27, P=$ 0.009).

Liming still had a highly significant effect on vegetation composition 70 years after the last treatment (Table 1: Plant community). In contrast, the effect of fertilization was only significant at the $10 \%$ level. Similar results were obtained when species presence-absence data were used instead of cover values (canonical correspondence analysis: liming, $F_{1,68}=2.12, P=$ 0.002 ; fertilization, $F_{1,68}=1.23, P=0.114$ ), indicating that limed and unlimed plots differed in terms of the presence of plant species. Indicator species analysis identified 13 species that were significantly more abundant either in limed plots or in unlimed plots (Table 2). The indicator species for liming are known as indicators for neutral soil reaction from the literature, whereas those indicating no liming are typical species of acid soils (Table 2), suggesting that the change in vegetation composition was due to the increased $\mathrm{pH}$. However, when soil $\mathrm{pH}$ was included in the redundancy analysis as a covariate, the effect of liming was still significant $\left(F_{1,67}=2.0, P=0.003\right)$. Plant species richness tended to be higher in limed plots than in unlimed plots $\left(31.6 \pm 0.61\right.$ species vs. $29.8 \pm 0.73$ species, $F_{1,68}=3.1$, $P=0.08)$, but was not affected by fertilization $(P=0.97)$.

The composition of the soil microbial community was significantly altered by liming, but not by fertilization (Table 1: Soil microbial community). When soil $\mathrm{pH}$ was included in the redundancy analysis as a covariate, the effect of liming was no longer significant $\left(F_{1,68}=1.4, P=\right.$ 0.171 ), suggesting that it was mediated by soil $\mathrm{pH}$. Indicator species analysis showed that the three PLFAs 10Me16:0, br17:0, and 10Me17:0 were indicator PLFAs for unlimed plots (Table 3). Bacterial biomass, fungal

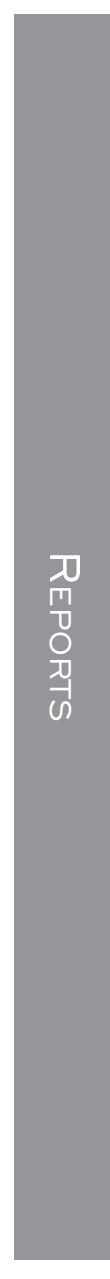


TABLE 2. Indicator plant parameters for liming and no-liming treatments revealed by indicator species analysis (Dufrene and Legendre 1997).

\begin{tabular}{|c|c|c|c|c|c|c|}
\hline \multirow{2}{*}{$\begin{array}{l}\text { Treatment and indicator } \\
\text { plant species }\end{array}$} & \multirow{2}{*}{$\begin{array}{l}\text { Indicator } \\
\text { value }\end{array}$} & \multicolumn{2}{|c|}{ Percent cover } & \multicolumn{2}{|c|}{ No. plots containing species } & \multirow[b]{2}{*}{$R$ value } \\
\hline & & Unlimed & Limed & Unlimed & Limed & \\
\hline \multicolumn{7}{|l|}{ Liming } \\
\hline Carex sempervirens & 59 & $1.5 \pm 0.40$ & $2.6 \pm 0.34$ & 20 & 36 & 7 \\
\hline Leontodon hispidus & 54 & $1.8 \pm 0.30$ & $2.8 \pm 0.35$ & 26 & 36 & 7 \\
\hline Lotus corniculatus & 51 & $1.2 \pm 0.23$ & $2.1 \pm 0.27$ & 23 & 33 & 7 \\
\hline Bartsia alpina & 50 & $0.8 \pm 0.12$ & $1.1 \pm 0.12$ & 26 & 35 & 7 \\
\hline Alchemilla vulgaris & 44 & $0.7 \pm 0.16$ & $1.2 \pm 0.21$ & 17 & 28 & \\
\hline Viola calcarata & 27 & $0.1 \pm 0.05$ & $0.5 \pm 0.15$ & 7 & 15 & 8 \\
\hline Anthyllis vulneraria. ssp. alpestris & 21 & $0.03 \pm 0.03$ & $0.3 \pm 0.12$ & 1 & 9 & 8 \\
\hline Selaginella selaginoides & 20 & 0.0 & $0.1 \pm 0.03$ & 0 & 8 & 7 \\
\hline \multicolumn{7}{|l|}{ No liming } \\
\hline Gentiana purpurea & 58 & $4.3 \pm 0.52$ & $1.9 \pm 0.31$ & 37 & 31 & 3 \\
\hline Campanula barbata & 54 & $2.9 \pm 0.31$ & $1.5 \pm 0.21$ & 35 & 28 & 1 \\
\hline Arnica montana & 54 & $5.1 \pm 0.50$ & $3.2 \pm 0.46$ & 37 & 32 & 3 \\
\hline Trifolium alpinum & 28 & $2.4 \pm 0.76$ & $0.4 \pm 0.18$ & 15 & 8 & 2 \\
\hline Vaccinium uliginosum & 18 & $0.4 \pm 0.17$ & $0.1 \pm 0.06$ & 9 & 2 & 1 \\
\hline
\end{tabular}

Notes: The indicator value is a measure combining information on the relative frequency and relative abundance of a species in a group of sites. Its maximum is 100 , when a species is present only in one group. Percent cover values are expressed as mean \pm SE. The $R$ (reaction) value (range 1-9), according to Ellenberg et al. (1991), indicates the realized ecological niche of the species in Central Europe. Low values indicate that species are typical for acidic soils, high values that they occur typically on base-rich soils. Landolt (1977) assigns a medium $R$ value to Carex sempervirens, which is equivalent to an $R$ value of 5 according to the Ellenberg system. All indicator values are statistically significant at $P<0.05$.

biomass, and AM fungal biomass did not differ between treatments.

\section{DisCusSION}

The experiment at the Schynige Platte set up by W. Lüdi in the early 1930s offers a unique opportunity to assess the response of a grassland ecosystem to a shortterm perturbation over a longer period of time than most other field experiments.

In contrast to other long-term studies in grasslands like the Park Grass and Cedar Creek experiments, where treatments were applied continuously over time (Dodd et al. 1994, Inouye and Tilman 1995, Wilson and Tilman 2002), the subset of the experimental plots analyzed in this study was last fertilized and limed in the early 1930s. Liming quickly increased the $\mathrm{pH}$ from $4.5-5$ at the beginning of the experiment up to neutrality in 1945 , and within a few years both treatments strongly changed the productivity and composition of the vegetation (Lüdi 1959). Then, with time, soil and plant communities are expected to asymptotically approach those of the control plots (Neubert and Caswell 1997). However,

TABLE 3. Indicator phospholipid fatty acids (PLFAs) for noliming treatments revealed by indicator species analysis (Dufrene and Legendre 1997) and their concentration in limed and unlimed plots.

\begin{tabular}{lccc}
\hline \hline PLFA & No liming & Liming & $P$ \\
\hline 10Me16:0 & $8.5 \pm 0.43$ & $7.0 \pm 0.33$ & 0.017 \\
br17:0 & $0.5 \pm 0.02$ & $0.4 \pm 0.02$ & 0.024 \\
10Me17:0 & $2.1 \pm 0.11$ & $1.7 \pm 0.09$ & 0.040 \\
\hline
\end{tabular}

Note: PLFA concentrations are given in $\mathrm{nmol} / \mathrm{g}$ dry soil \pm SE. our results show that 70 years after the last treatment, the effects of liming on vegetation, soil microbial community, and on soil chemistry were still detectable.

Liming has generally strong effects on plant communities as shown during both short and long-term experiments, and these effects have been attributed to the change in soil pH (Tilman et al. 1994, Nilsson et al. 2002). At our study site, the $\mathrm{pH}$ of the limed plots remained close to neutrality until 1955 , and then slowly returned to about pH 6.3 in 1990 (O. Hegg, unpublished data). In 2002, i.e., after 70 years, the $\mathrm{pH}$ of limed plots was still significantly higher than that of control plots. The difference was relatively small (5.14 vs. 4.97$)$, but nevertheless represented a $50 \%$ higher concentration of hydrogen ions in the unlimed plots. We hypothesize that the current differences in plant community composition reflect the much larger differences in $\mathrm{pH}$ in the past, rather than the differences today. This may also explain why no persistent effects of liming on productivity could be detected in the greenhouse experiment. The plant community at the Schynige Platte consists mainly of long-lived, clonal perennials that should respond slowly to a gradual change in environmental conditions (Milchunas and Lauenroth 1995, Körner 1999).

In contrast, soil microorganisms are often short lived, have high turnover rates, and are thought to recover quickly from disturbance (Wardle 2002). Nevertheless, we found significant effects of liming on the composition of the PLFAs in the soil 70 years after the last treatment. This suggests that, despite the relatively small differences in soil $\mathrm{pH}$ and no evidence for differences in soil organic matter content and productivity, the limed plots continue to provide environmental conditions for belowground organisms that differ from those of the 
control plots. Experimental manipulation of the soil $\mathrm{pH}$ in forests resulted in consistent changes in PLFA patterns, suggesting that $\mathrm{pH}$ is a key determinant of soil microbial community composition (Frostegård et al. 1993, Bååth et al. 1995, Pennanen et al. 1998, Bååth and Anderson 2003). Pennanen et al. (1998), in results similar to our study, found that even a small change in soil $\mathrm{pH}$ of 0.2 units significantly influenced the composition of the soil microbial community. In our study, both the results of the multivariate analysis and the response of individual PLFAs to liming indicated that the effects of the liming treatment were mediated by its effect on soil $\mathrm{pH}$. In the experiment at the Schynige Platte, fatty acids that are typical for low pH (10Me16:0, 10Me17:0) were more abundant in unlimed plots (Frostegård et al. 1993, Pennanen et al. 1998, Bååth and Anderson 2003).

In regions like the Bernese Oberland where rainfall considerably exceeds evaporation, leaching of cations such as $\mathrm{Ca}$ is generally thought to be high due to significant water movement through the soil profile (Jenny 1980). However, the amount of exchangeable Ca in the soil of the limed plots, 70 years after the last liming, was still $\sim 22 \%$ higher than in the control plots. Similarly, Marion et al. (1993) found that loss of exchangeable $\mathrm{Ca}$ from soils with a $\mathrm{pH}$ level comparable to that of our limed plots ( $\mathrm{pH} \sim 7$ in 1945) was slow in an arctic ecosystem. Based on a study along a primary successional chronosequence on an initially alkaline, Carich soil in Alaska, Marion et al. (1993) estimated that it took 250 years until the amount of exchangeable $\mathrm{Ca}$ had declined by $75 \%$ and the soil $\mathrm{pH}$ level by $2-3$ units.

A possible mechanism by which the long-term effects of liming can be explained is that the significant changes in soil $\mathrm{pH}$ originally induced by liming have subsequently been maintained by positive feedbacks between belowground and aboveground ecosystem components (Wardle 2002). Soil pH is a key determinant of microbial community biomass and composition (Bååth and Anderson 2003), and has been shown to have a large influence on ecosystem processes such as litter decomposition (e.g., through its effect on degradation rates of phenolic compounds [Pind et al. 1994]) and nutrient mineralization. As a consequence, soils with a $\mathrm{pH}$ close to neutrality generally have a higher nutrient availability than soils with a $\mathrm{pH}$ of 4 to 5 (Chapin et al. 2002). Therefore, the changes in the belowground ecosystem induced by liming are likely to have favored plant species that have high rates of nutrient acquisition, high relative growth rates, and high tissue nutrient concentrations. Leaf litter of these plants is favorable to decomposers and breaks down more rapidly than that of plant species adapted to low-nutrient conditions (Cornelisson et al. 1999). The increased leaf litter quality in turn is likely to retain the soil microbial composition and the magnitude of microbial processes originally induced by liming. This feedback between aboveground and belowground food webs may generate relatively stable, mutualistic associations and thereby decrease the rate at which ecosystem components or processes return to their original state, or even shift the ecosystem to an alternative self-organized state.

Similar to the effects of liming, fertilization also resulted in a significant change in plant community composition and an increase in biomass production within the first years after application (Lüdi 1959). However, already in the early 1940s both biomass production and the abundance of plant species that had initially responded positively to fertilization began to decrease (Lüdi 1959). Correspondingly, we found only marginal effects of NPK fertilization on plant community composition, and no effects on productivity and soil microbial composition. These results suggest that the subalpine acid grassland ecosystem at the Schynige Platte has a higher resilience to short-term fertilization than to short-term liming, and that the measured biotic and abiotic characteristics of the fertilized plots have again approached those of the control plots.

In summary, the results of this study provide strong evidence that short-term and small-scale perturbations can have very long-lasting effects on mountain grasslands, despite their high species richness, which is commonly seen as an indicator of high resilience (Hooper et al. 2005). The different long-term effects of liming and fertilization on soil chemistry and the composition of the plant and microbial community indicate that the resilience of mountain grasslands may differ depending on the type of ecosystem changes induced by the perturbation. We propose that the resilience of mountain ecosystems may be particularly low in response to perturbations that substantially alter soil $\mathrm{pH}$ or other key determinants of belowground processes.

\section{ACKNOWLEDGMENTS}

We thank the Geschäftsleitung of the Alpengarten Schynige Platte for allowing us to work on the Lüdi plots, and Christine Alewell, two anonymous reviewers, and the subject matter editor for valuable comments on the manuscript. This work was supported by the Swiss Priority Program "Landscapes and Habitats of the Alps," a research project of the Swiss National Science Foundation (grant 4048-064424).

\section{Literature Cited}

Bååth, E., and T. H. Anderson. 2003. Comparison of soil fungal/bacterial ratios in a $\mathrm{pH}$ gradient using physiological and PLFA-based techniques. Soil Biology and Biochemistry 35:955-963.

Bååth, E., A. Frostegård, T. Pennanen, and H. Fritze. 1995. Microbial community structure and $\mathrm{pH}$ response in relation to soil organic-matter quality in wood-ash fertilized, clear-cut or burned coniferous forest soils. Soil Biology and Biochemistry 27:229-240.

Chapin, F. S., III, P. A. Matson, and H. A. Mooney. 2002. Principles of terrestrial ecosystem ecology. Springer Verlag, New York, New York, USA.

Cornelissen, J. H. C., N. Perez-Harguindeguy, S. Diaz, J. P. Grime, B. Marzano, M. Cabido, F. Vendramini, and B. Cerabolini. 1999. Leaf structure and defence control litter decomposition rate across species and life forms in regional floras on two continents. New Phytologist 143:191-200. 
DeAngelis, D. L., S. M. Bartell, and A. L. Brenkert. 1989 Effects of nutrient recycling and food-chain length on resilience. American Naturalist 134:778-805.

Dodd, M. E., J. Silvertown, K. McConway, J. Potts, and M. Crawley. 1994. Stability in the plant communities of the Park Grass Experiment: the relationships between species richness, soil $\mathrm{pH}$ and biomass availability. Philosophical Transactions of the Royal Society B: Biological Sciences 346:185-193.

Dufrene, M., and P. Legendre. 1997. Species assemblages and indicator species: the need for a flexible asymmetrical approach. Ecological Monographs 67:345-366.

Ellenberg, H., H. E. Weber, R. Düll, V. Wirth, W. Werner, and D. Paulißen. 1991. Zeigerwerte von Pflanzen in Mitteleuropa. Third edition. Goltze, Göttingen, Germany.

Frostegård, A., and E. Bååth. 1996. The use of phospholipid fatty acid analysis to estimate bacterial and fungal biomass in soil. Biology and Fertility of Soils 22:59-65.

Frostegård, A., E. Bååth, and A. Tunlid. 1993. Shifts in the structure of soil microbial communities in limed forests as revealed by phospholipid fatty-acid analysis. Soil Biology and Biochemistry 25:723-730.

Gunderson, L. H. 2000. Ecological resilience - in theory and application. Annual Review of Ecology and Systematics 31: 425-439.

Hedlund, K. 2002. Soil microbial community structure in relation to vegetation management on former agricultural land. Soil Biology and Biochemistry 34:1299-1307.

Hegg, O., U. Feller, W. Dähler, and C. Scherrer. 1992. Long term influence of fertilization in a Nardetum. Vegetatio 103: $151-158$

Holling, C. S. 1973. Resilience and stability of ecological systems. Annual Review of Ecology and Systematics 4:1-23.

Hooper, D. U., et al. 2005. Effects of biodiversity on ecosystem functioning: a consensus of current knowledge. Ecological Monographs 75:3-35.

Inouye, R. S., and D. Tilman. 1995. Convergence and divergence of old-field vegetation after $11 \mathrm{yr}$ of nitrogen addition. Ecology 76:1872-1887.

Jenny, H. 1980. The soil resource: origin and behavior. Springer Verlag, New York, New York, USA.

Johnston, A. E., K. W. T. Goulding, and P. R. Poulton. 1986. Soil acidification during more than 100 years under permanent grassland and woodland at Rothamsted. Soil Use and Management 2:3-10.

Körner, C. 1999. Alpine plant life. Springer Verlag, Berlin, Germany.

Landolt, E. 1977. Ökologische Zeigerwerte zur Schweizer Flora. Stiftung Rübel, Zürich, Switzerland.

Lavorel, S., A.-H. Prieur-Richard, and K. Grigulis. 1999. Invasibility and diversity of plant communities: from pattern to processes. Diversity and Distributions 5:41-49.

Leps, J., J. Osbornova-Kosinova, and M. Rejmanek. 1982. Community stability, complexity and species life-history strategies. Vegetatio 50:53-36.

Leps, J., and P. Smilauer. 2003. Multivariate analysis of ecological data using CANOCO. Cambridge University Press, Cambridge, UK.

Lüdi, W. 1948. Die Pflanzengesellschaften der Schynige Platte bei Interlaken und ihre Beziehung zur Umwelt. Veröffentlichung Geobotanisches Institut ETH, Stiftung Rübel 23: 400.

Lüdi, W. 1959. Versuche zur Alpweidenverbesserung auf der Schynigen Platte bei Interlaken. Alpengarten Schynige Platte, Interlaken, Switzerland.

MacGillivray, C. W., and J. P. Grime. 1995. Testing predictions of the resistance and resilience of vegetation subjected to extreme events. Functional Ecology 9:640-649.
Marion, G. M., K. Cleve, and C. T. Dyrness. 1993. Calcium carbonate precipitation-dissolution along a forest primary successional sequence on the Tanana River floodplain, interior Alaska. Canada Journal of Forest Research 23: 923-927.

May, R. M. 1973. Stability and complexity in model ecosystems. Princeton University Press, Princeton, New Jersey, USA

McCune, B., and M. J. Mefford. 1999. PC-ORD for Windows. MjM Software Design, Gleneden Beach, Oregon, USA.

Milchunas, D. G., and W. K. Lauenroth. 1995. Inertia in plant community structure: state changes after cessation of nutrient-enrichment stress. Ecological Applications 5:452458.

Moore, J. C., P. C. de Ruiter, and H. W. Hunt. 1993. Influence of productivity on the stability of real and model ecosystems. Science 261:906-908.

Mueller-Dombois, D., and H. Ellenberg. 1974. Aims and methods of vegetation ecology. John Wiley and Sons, New York, New York, USA.

Neubert, M. G., and H. Caswell. 1997. Alternatives to resilience for measuring the responses of ecological systems to perturbations. Ecology 78:653-665.

Nilsson, M.-C., D. A. Wardle, O. Zackrisson, and A. Jäderlund. 2002. Effects of alleviation of ecological stresses on an alpine tundra community over an eight-year period. Oikos 97:3-17.

Olsson, P. A. 1999. Signature fatty acids provide tools for determination of the distribution and interactions of mycorrhizal fungi in soil. FEMS Microbiology Ecology 29:303-310.

Pennanen, T., H. Fritze, P. Vanhala, O. Kiikkila, S. Neuvonen, and E. Bååth. 1998. Structure of a microbial community in soil after prolonged addition of low levels of simulated acid rain. Applied and Environmental Microbiology 64:21732180.

Pind, A., C. Freeman, and M. A. Lock. 1994. Enzymic degradation of phenolic materials in peatlands - measurement of phenol oxidase activity. Plant and Soil 159:227-231.

R Development Core Team. 2004. R: a language and environment for statistical computing. 〈http://cran.r-project.org

Scheffer, M., S. Carpenter, J. A. Foley, C. Folke, and B. Walker. 2001. Catastrophic shifts in ecosystems. Nature 413: 591-596.

Schimel, J. P., and J. Bennett. 2004. Nitrogen mineralization: challenges of a changing paradigm. Ecology 85:591-602.

ter Braak, C. F., and P. Smilauer. 1999. Canoco for Windows. Center for Biometry, Wageningen, The Netherlands.

Tilman, D., M. E. Dodd, J. Silvertown, P. R. Poulton, A. E. Johnston, and M. J. Crawley. 1994. The Park Grass Experiment: insights from the most long-term ecological study. Pages 287-303 in R. A. Leigh and A. E. Johnston, editors. Long-term experiments in agricultural and ecological sciences. CABI, Wallingford, UK.

Tilman, D., and J. A. Downing. 1994. Biodiversity and stability in grasslands. Nature 367:363-365.

Tilman, D., and C. Lehman. 2001. Human-caused environmental change: impacts on plant diversity and evolution. Proceedings of the National Academy of Sciences (USA) 98: $5433-5440$

van den Wollenberg, A. L. 1977. Redundancy analysis: an alternative for canonical correlation analysis. Psychometrika 42:207-219.

Wardle, D. A. 2002. Communities and ecosystems - linking the aboveground and belowground components. Princeton University Press, Princeton, New Jersey, USA.

Wilson, S. D., and D. Tilman. 2002. Quadratic variation in oldfield species richness along gradients of disturbance and nitrogen. Ecology 83:492-504. 